\title{
ON THE PREDICTION OF NON-LINEAR CREEP STRAINS
}

\author{
Robertas Balevičius ${ }^{1}$, Eugedijus Dulinskas ${ }^{2}$ \\ ${ }^{1}$ Department of Reinforced Concrete and Masonry Structures, Vilnius Gediminas Technical University, \\ Sauletekio al. 11, LT-10223 Vilnius, Lithuania \\ ${ }^{2}$ Department of Bridges and Special Structures, Vilnius Gediminas Technical University, \\ Saulètekio al. 11, LT-10223 Vilnius, Lithuania \\ E-mail: ${ }^{1}$ Robertas.Balevicius@vgtu.lt; ${ }^{2}$ skmml@vgtu.lt \\ Received 28 Sept. 2009; accepted 22 May 2010
}

\begin{abstract}
In the short term, the Euorocode-based techniques will be implemented as the main design specifications for structural engineers from the member-states of the European Union instead of the national standards. Therefore, it is of primary importance draw attention to the observed inaccuracies, particularly, in predicting non-linear creep strains according to EC-2. The analysis performed was mainly focused on an inconsistency elimination observed in the original EC-2 approach, when transition from the linear to non-linear creep laws for a constant compressive stress is required. A recent CEN corrigendum eliminating the observed inconsistency was also discussed in detail.

In this context, similar techniques which were reported in the literature for predicting the creep non-linearity function were analysed to account for the results obtained. It was particularly demonstrated that the recent CEN amendment results in an extremely enhanced creep strain for low strength concrete. A comparison of the creep non-linearity functions with experimental test results was also considered.
\end{abstract}

Keywords: Codes of practice \& standards, concrete creep, non-linear creep strain, creep nonlinearity function.

\section{Introduction}

High compressive stress seriously affects the long-term performance of the plain, reinforced or prestressed concrete structures causing their non-linear creep behaviour. As a result, this may lead to instability problems, element failures and can overcome advantages for developments of the high-strength materials. Over the years, a great deal of attempt describing the non-linear creep phenomena has been a subject of open discussions.

The main approaches for predicting creep nonlinearity could be generalized as follows:

- rheological models (Freudenthal and Roll 1958; Bažant and Asghari 1977), i.e., spring and dashpot elements are combined to achieve nonlinear creep behaviuor;

- the transformed short-term models (Wagner 1958; Chovichien et al. 1973; Bačinskas et al. 2001), i.e., distortion in an instantaneous stressstrain path is provided by using a linear creep coefficient;

- the creep non-linearity function technique (NIIZHB 1988; Александровский, Попкова 1971; Grasser and Kraemer 1985), i.e., creep strain is expressed as a sum of linear and nonlinear creep strains;

- the creep non-linearity function technique (EN 1992-1-1; Bažant and Kim 1991; Bažant and Prasannan 1989), i.e., creep strain is defined as a multiplication of linear creep strain by the factor accounting for the non-linear dependence in stress.

The latter methods, based on the well-known shortcomings, represent, however, a suitable way for the evaluation of non-linear creep deformations for engineering purposes. Therefore, they are recommended as the design specifications for the code EC-2 (EN 1992-1-1) and NIIZHB (1988). However, the comparative analysis of creep non-linearity functions and test data can hardly be found in the literature on the problem. For instance, the creep non-linearity function is not defined in codes e.g., BS8110, ACI 318M-05.

Generally, it should be pointed out that the Eurocode neglects the strong nonlinear deviations from the principle of superposition due to simultaneous variation of moisture content, i.e., the strain produced by a stress increment applied at any time is affected by any stress applied either earlier or later. Also, the Eurocode ignores the nonlinear tensorial time-dependent damage, related to a progressive microcracking of concrete, which is sometimes misrepresented as a nonlinear creep.

Soon, the Euorocode-based techniques will be implemented as the main design specifications for structural engineers from the member-states of the European Union instead of the national standards. Therefore, it is of primary importance to describe the observed inaccuracies, particularly, in predicting non-linear creep strains according to code EC-2 (EN 1992-1-1). 


\section{Background}

Let us consider creep non-linearity evaluation by equation (3.7) given in the code EC2 (EN 1992-1-1). Thus, when the constant compressive stress, $\sigma_{c}$ applied at an age $t_{0}$ exceeds the value of $0.45 f_{c k}\left(t_{0}\right)$ (where $f_{c k}\left(t_{0}\right)$ is the characteristic compressive cylinder strength), then, creep non-linearity should be considered. Therefore, the final (for, $t=\infty$ ) non-linear creep strain $\varepsilon_{c c}\left(\sigma_{c}, \infty, t_{0}\right)$ depends on the stress applied and is expressed as:

$$
\varepsilon_{c C}\left(\sigma_{c}, \infty, t_{0}\right)=\frac{\sigma_{c}}{E_{c 0}} F\left(k_{\sigma}\right) \varphi\left(\infty, t_{0}\right),
$$

where $E_{c 0}$ is the tangent modulus of elasticity at time of loading $t_{0}, \varphi\left(\infty, t_{0}\right)$ is the final creep coefficient, $F\left(k_{\sigma}\right)$ is the creep non-linearity function, and $k_{\sigma}$ is the stress and the mean concrete compressive cylinder strength ratio. According to original EC2 (EN 1992-1-1) approach, the creep non-linearity function $F\left(k_{\sigma}\right)$ is defined by the ratio of stress to the mean compressive cylinder strength, $f_{c m}\left(t_{0}\right)$ as follows:

$$
F\left(k_{\sigma}\right)=e^{1.5\left(k_{\sigma}-0.45\right)}, F\left(k_{\sigma}\right) \equiv F\left(k_{\sigma, c m}\right),
$$

where

$$
k_{\sigma, c m}=\frac{\sigma_{c}}{f_{c m}\left(t_{0}\right)} \text {. }
$$

\section{Results and discussion}

Since the creep non-linearity takes a place at the stress level pertained to the characteristic value of cylinder strength (EN 1992-1-1), while the non-linearity function (2) depends on the ratio of stress to the mean value of cylinder strength, therefore, the transition over stress ratios must be adopted. Moreover, to justify the creep non-linearity function by test data, the stress ratio should always be related to the mean value of compressive concrete strength.

Relying on formula (3), the compressive stress may generally be expressed in terms of the mean compressive cylinder strength, $\sigma_{c}=k_{\sigma, c m} f_{c m}\left(t_{0}\right)$, or in terms of the characteristic compressive cylinder strength, $\sigma_{c}=k_{\sigma, c k} f_{c k}\left(t_{0}\right)$. In spite of the fact which of the cylinder compressive strengths (mean or characteristic) is theoretically employed in the approach, the stress acting on the specimen must be the same, i.e., $\sigma_{c}=k_{\sigma, c m} f_{c m}\left(t_{0}\right)=k_{\sigma, c k} f_{c k}\left(t_{0}\right)$. This simply yields

$$
k_{\sigma, c m}=k_{\sigma, c k}\left(1-\frac{8}{f_{c m}\left(t_{0}\right)}\right),
$$

where $k_{\sigma, c k}=\frac{\sigma_{c}}{f_{c k}\left(t_{0}\right)}$ is stress and the characteristic compressive cylinder strength ratio.

By unifying the stress level, at which the creep-nonlinearity emerges, with the stress-strength ratio defined in the creep non-linearity function, the substitution of for- mula (4) into the relationship (2) is performed. It allowed us to plot the graph of the creep non-linearity function versus the ratio of stress to the mean value of compressive cylinder strength (Fig. 1) as well as performing the further comparison with test data.

A plot representing the ratio of stress to the mean value of compressive cylinder strength against the total (instantaneous + creep) strain for low- and high-strength concrete is shown in Fig. 2.

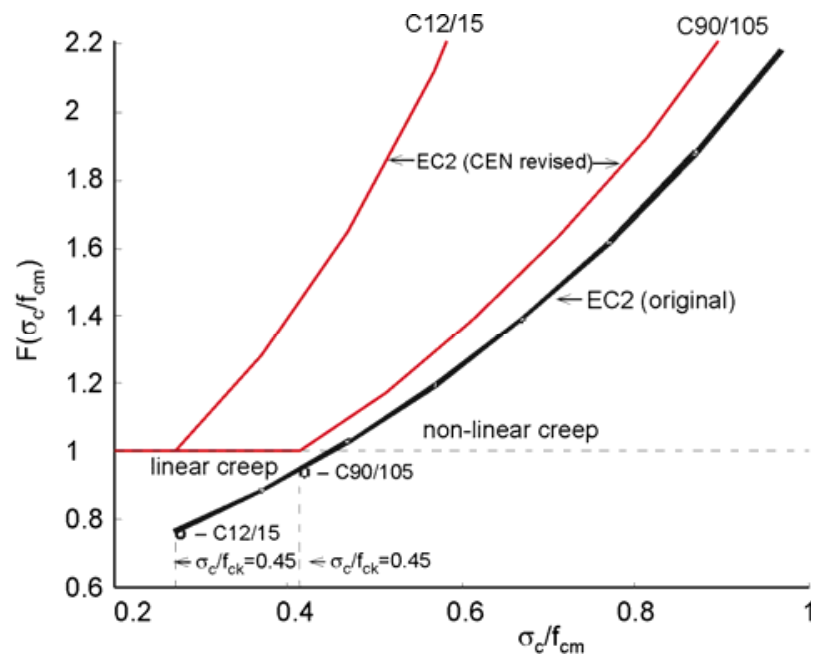

Fig. 1. Creep non-linearity function vs ratio of stress to mean compressive cylinder strength

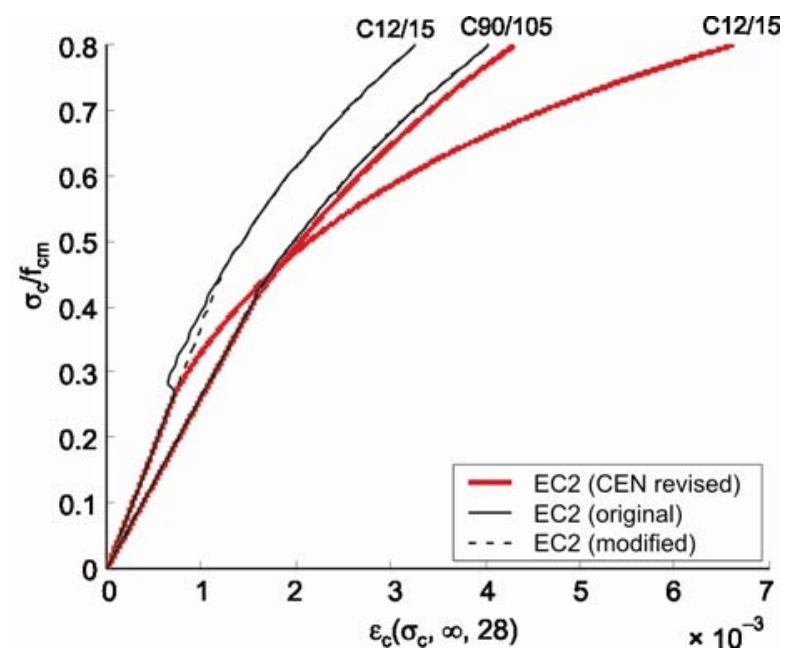

Fig. 2. Ratio of stress to mean compressive cylinder strength vs total strain of concrete

In Fig. 1, the inconsistency of the creep nonlinearity function of EC2 (EN 1992-1-1) original approach can be clearly indicated, i.e., the values of this function cannot be lower than a unity, which is manifested in the classical theory of the creep. In other words, the transition limit between the linear and non-linear laws of creep deformation is trespassed due to the inconsistency in stress-strength ratio resulted from the incorrect application of the mean and characteristic values of compressive cylinder strength to define the creep nonlinearity function. 
The graphs depicted in Fig. 2 show the influence of the above-mentioned inconsistency on the prediction of the total compressive strain of concrete. As can be observed in Fig. 2, with the commencement of non-linear deformation, the concrete strain (thin solid lines) suddenly decreases (recovers) under a small increment of stress-strength ratio, inducing a discontinuity region in the stress-strain path. This is more evident for the lowstrength concrete, while, for the high-strength concrete, this discontinuity is less discernible.

Consequently, an elimination of the observed inconsistency is adopted here assuming that the stress limit, separating the linear and non-linear creep laws, is dependent on the mean value of compressive concrete strength. The modified prediction of concrete strains is plotted in Fig. 2 by dashed lines.

It should be noted that this is a reasonable modification, which does not require the correction of the creep non-linearity function, but, in turn, giving a quite close fit with the experimental test data considered below.

In the context of modified and the original EC-2 models we consider the alternative creep non-linearity functions of different complexity found in literature. In NIIZHB (1988) approach, the creep non-linearity function is given as:

$$
F\left(k_{\sigma}\right)=1+v_{c} k_{\sigma}^{4}, F\left(k_{\sigma}\right) \equiv F\left(k_{\sigma, p r}\right),
$$

where $k_{\sigma, p r}=\frac{\sigma_{c}}{f_{p r}\left(t_{0}\right)}$ the ratio of stress to the mean value of the compressive prism strength, $v_{C}$ is the coefficient defining the increase in creep strain during the concrete failure and depends on the compressive prism strength.

Indeed, the NIIZHB (1988) model conveniently represents a unified description for the creep problem. In particular, the first term in formula (5) describes linear creep, while the second term is attached to non-linear creep strain.

In Bažant, Kim’s (1991) and Bažant, Prasannan’s (1989) approaches, the creep non-linearity functions are defined as follows:

$$
\begin{aligned}
& F\left(\sigma_{c}\right)=\frac{1+s^{2}}{1-\Omega}, \\
& F\left(\sigma_{c}\right)=\frac{1+3 s^{2}}{1-\Omega},
\end{aligned}
$$

where $s=\sigma_{c} / f_{c}, \Omega=s^{10}$.

These models are attributed to the damage modeling at a high stress-strength ratio. Justifications of various aspects of the models by statistical comparisons with all the data in the internationally accepted RILEM data bank and diverse refinements were developed as B3 model (Bažant and Baweja 2000).

Now, let us compare the above techniques with the experimental test data. For this end, in c Fig. 3, we plot creep non-linearity functions derived from the experimental tests data obtained by Smadi et al. (1985), Prokopovich and Temnov (Прокопович, Темнов 1988), Rüsch (1960) for low ( $\left.f_{c m}=20-25 \mathrm{MPa}\right)$, medium $\left(f_{c m}=\right.$
32-40 MPa), and high $\left(f_{c m}=55-65 \mathrm{MPa}\right)$ strengths of concrete against the theoretical ones.

In the comparative analysis, the following aspects should be concerned. In particular, a relation of $F\left(\sigma_{c} / f_{c m}\left(t_{0}\right)\right)=\varepsilon_{c c}\left(\sigma_{c} / f_{c m}\left(t_{0}\right), t, t_{0}\right) / \varepsilon_{c c}\left(t, t_{0}\right) \quad$ is applied deriving the creep non-linearity function from the experimental stress-strain curves. The mean value of the compressive prism strength, used in NIIZHB (1988) approach, was divided by the factor approximately equal to $\sim 0.95$ for obtaining the mean value of compressive cylinder strength. For loading duration $t-t_{0}$ more than by about 30 days, a different nature of the development of nonlinear creep strains with time may be ignored postulating well-experimentally defined fact about the affinity of creep strains (cf. Temnov's and Rüsch test data, in Fig. 3). Also, the values of the experimental strains may be significantly affected by the strain rates applied. This fact may probably be attributed to the increased values of the creep non-linearity function derived from the test data by Rüsch (Fig. 3).

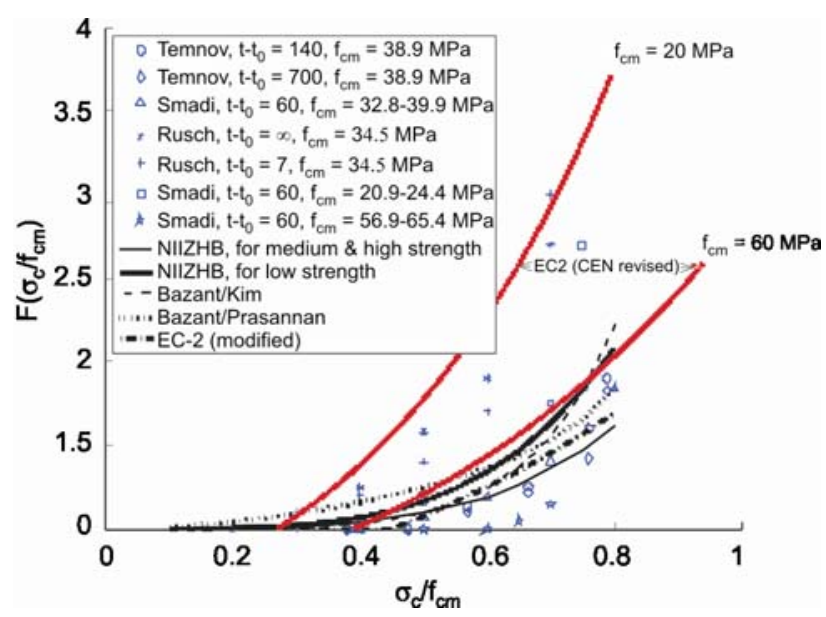

Fig. 3. Comparison of the creep non-linearity functions with the experimental test data

As can be seen in Fig. 3, all approaches (including our modified original EC2 model) do not produce the values of creep non-linearity function lower than unity. Moreover, all models result in similar values of the creep non-linearity function over the considered stress-strength ratio range. However, some peculiarities can be observed.

In particular, the values determined by using our modified EC2 model could rather be treated as a conservative approach, resulting in the average prediction of the creep non-linearity function for low- and high-strength concretes. The same fact may be attributed to Bazant, Prasannan's and Bazant, Kim's models, while the latter technique results in an improved fit with the experimental test data, particularly, for the lower level of stressstrength ratios. On the contrary, NIIZHB (1988) technique is developed in a more complex manner, manifesting the dependency of the creep non-linearity function on the concrete strength, which was highlighted in various experimental investigations as well as in those plotted in Fig. 3. In particular, NIIZHB (1988) model gives a good fit to the experimental data for low-strength concrete. For 
high-strength concrete (cf. Fig. 3), however, NIIZHB (1988) technique overestimates the creep strain.

Finally, consider the CEN corrigendum January 2008, revising the code EC2 (EN 1992-1-1), appeared as EN 1992-1-1:2004/AC:2008. A revision concerning code EC-2 equation (3.7) has been made by replacing the stress-strength ratio, $\sigma_{c} / f_{c m}\left(t_{0}\right)$ by the ratio, $\sigma_{c} / f_{c k}\left(t_{0}\right)$. Therefore, the graphs, denoted as EC2 (CEN revised), were also included in Figs. 1, 2 and Fig. 3 to consider the amendment made.

Now, CEN revision (EN 1992-1-1:2004/AC:2008) eliminates the above-mentioned inconsistency, unifying the stress-strength ratio defined in function (2) with the ratio, at which the creep-non-linearity originates, by using the characteristic compressive cylinder strength. As a result, the CEN-revised creep non-linearity function correctly produces a unity for the linear creep law, and gives the values greater than unity, when the creep nonlinearity takes place (Fig. 1). Furthermore, now, a wellknown concrete strength (cf. C12/15 and C90/105, in Fig. 1) influence on the creep non-linearity function versus the ratio of stress to the mean compressive cylinder strength can be discerned, since $k_{\sigma, c m}<k_{\sigma, c k}$ (due to $\left.f_{c m}\left(t_{0}\right)>f_{c k}\left(t_{0}\right)\right)$.

However, as can be seen in Fig. 2, CEN amendment (EN 1992-1-1:2004/AC:2008) extremely enhances the creep strains for low strength concrete and highly overestimates the experimental test results (Fig. 3). Meanwhile, the proposed modification gives considerably more realistic prediction of the creep non-linearity function vs experimental test results as well as producing the results similar to those yielded by other approaches.

\section{Concluding remarks}

An inconsistency in the creep non-linearity function of the code EC2 (EN 1992-1-1) has been clearly indicated. As a result of incorrect application of stress-strength ratio in predicting the separating stress limit for linear/nonlinear creep laws, a discontinuity region in the stressstrain path was defined. The inconsistency observed was eliminated in a quite reasonable way by relating this limit to the mean value of compressive concrete strength without the modification of the creep non-linearity function. A good agreement with the experimental test data has been achieved.

A recent CEN revision (EN 1992-1-1:2004/AC: 2008) also eliminated the observed inconsistency; however it extremely enhanced creep strains for low strength concrete, as well as resulting in overestimation of the experimental test results.

\section{References}

ACI 318M-05. American concrete institute. Building Code Requirements for Structural Concrete and Commentary. ACI: Black \& Veatch, 2005.

Bačinskas, D.; Kaklauskas, G.; Vainiūnas, P. 2001. Layered approach for long-term deflections analysis of reinforced concrete beams, Journal of Civil Engineering and Management 7(5): 380-385.

Bažant, Z. P.; Kim, J. K. 1991. Improved prediction model for time-dependent deformations of concrete: Part 2 - Basic creep, Materials and Structures 24(6): 409-421. doi:10.1007/BF02472014

Bažant, Z. P.; Prasannan, S. 1989. Solidification theory for concrete creep. I: Formulation, Journal of Engineering Mechanics 115(8): 1691-1703. doi:10.1061/(ASCE)0733-9399(1989)115:8(1691)

Bažant, Z. P; Baweja, S. 2000. Creep and shrinkage prediction model for analysis and design of concrete structures: Model B3, Adam Neville Symposium: Creep and Shrinkage - Structural Design Effects, ACI SP-194: 1-83.

Bažant, Z. P.; Asghari, A. A. 1977. Constitutive law for nonlinear creep of concrete, Journal of the Engineering Mechanics Division 103(1): 113-124.

BS 8110. British standards institution. Structural Use of Concrete. Part 1: 1997, Part 2: 1985, Part 3: 1985. BSI, Milton Keynes, 1997/1985.

Chovichien, V.; Gutzwiller, M. J.; Lee, R. H. 1973. Analysis of reinforced concrete columns under sustained load, American Concrete Institute Journal 70(10): 692-699.

EN 1992-1-1:2004/AC:2008 (E). European Committee for Standardization. CEN corrigendum. Brussels: CEN, 2008.

EN 1992-1-1:2004: Part1-1. European Committee for Standardization. Eurocode 2. Design of concrete structures. General rules and rules for buildings, CEN, Brussels, 2004.

Freudenthal, A. M.; Roll, F. 1958. Creep and creep recovery of concrete under high compressive stress, American Concrete Institute Journal 54(12): 1111-1142.

Grasser, E.; Kraemer, U. 1985. The creep of concrete under high centric and eccentric compression, Deutscher Ausschu $\beta$ für Stahlbeton, H. 358. Berlin: Verlag Ernst \& Sohn (in German).

Rüsch, H. 1960. Researches toward a general flexural theory for structural concrete, American Concrete Institute Journal 57(7): 1-28.

Smadi, M. M.; Slate, F. O.; Nilson, H. N. 1985. High-, mediumand low-strength concretes subjected to sustained overloads - strains, strengths, and failure mechanisms, American Concrete Institute Journal 84(3): 657-664.

Wagner, O. 1958. The creep of unsealed concretes, Deutscher Ausschu $\beta$ für Stahlbeton, H. 131. Berlin: Verlag Ernst \& Sohn (in German).

Александровский, С. В.; Попкова, О. М. 1971. Нелинейные деформации бетона при сложных режимах загружения [Aleksandrovskiy, S. V.; Popkova, O. M. Non-linear deformation of concrete under variable stress regimes], Бетон и железобетон [Beton i Zhelezobeton] 1: 27-32.

Прокопович, И. Е.; Темнов, И. И. 1988. Несущая способность сжатых железобетонных стержней при кратковременном и длительном нагружениях [Prokopovich, I. E.; Temnov, I. I. Short- and long-term resistance of concrete members in compression], Строительные конструкиии [Civil Engineering Structures] 41: 65-69.

Рекомендации по учету ползучести и усадки бетона при расчете бетонных и железобетонных конструкций. 1988 [Specifications for evaluation of the concrete creep and shrinkage in the analysis of concrete and reinforced concrete structures]. Научно-исследовательский институт бетона и железобетона [Concrete and reinforced concrete research and technological institute]. Москва: Госстрой СССР. 122 с. 


\section{APIE NETIESINIŲ VALKŠNUMO DEFORMACIJŲ NUSTATYMĄ}

\section{R. Balevičius, E. Dulinskas}

\section{S a n tra u a}

Artimiausiu metu nacionalines normas pakeis Europos normos, kurios taps privalomu normatyviniu dokumentu Europos Sajungos šaliu statybos inžinieriams. Todèl labai svarbu konstatuoti ir patikslinti jose pastebètus netikslumus. Straipsnyje akcentuojamas normų EC2 metodikoje pastebėtas valkšnumo deformacijų nesutapimas, kai reikalingas perèjimas iš tiesinių valkšnumo deformacijų prie netiesinių. Pateikiama žinomų metodų ir eksperimentinių tyrimų rezultatų lyginamoji analizè, autoriu siūlymai bei detaliai nagrinèjamas neseniai išleistas CEN komiteto taisymas. Atlikus analizę nustatyta, kad CEN korektūra lemia nepaprastai dideles mažo stiprumo betonų netiesinio valkšnumo deformacijas.

Reikšminiai žodžiai: normos, standartai, betono valkšnumas, netiesinė valkšnumo deformacija, valkšnumo netiesiškumo funkcija.

Robertas BALEVIČIUS. MSc (CE), PhD at the Department of Reinforced Concrete and Masonry Structures of Vilnius Gediminas Technical University, Lithuania. Research interests: mechanics of time-dependent materials, finite and discrete element methods.

Eugedijus DULINSKAS. PhD, Assoc. Professor. Dept of Bridges and Special Structures. Head Research Laboratory of Buildings, Structures and Materials. In 1986-1990 joint research of concrete structures and probations at Germany. Author of over 80 articles and 5 monographs. Research interests: mechanics of concrete, concrete and masonry structures, mechanics of time-dependent materials, renovation and strengthening of buildings and structures. 